Indexed keywords

Topics of prominence

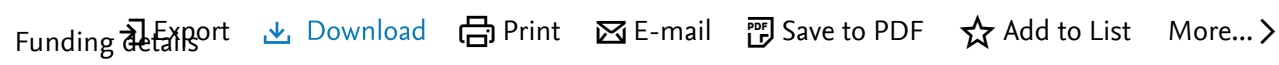

View at Publisher|

Document type

Conference Paper

Source type

Conference Proceedings

ISBN

978-099604376-2

DOI

10.14455/isec.res.2019.119

View more $\vee$

ISEC 2019 - 10th International Structural Engineering and Construction Conference • 2019 • 10th International Structural Engineering and Construction Conference, ISEC 2019, 20 May 2019 - 25 May 2019

\section{Neural network and probabilty based cost expectation limit model for residential building cost}

Amusan L., Opeyemi J., Ebuoluwa A., Omuh I.

国 Save all to author list

Dept of Building Technology, Covenant University, Ota, Nigeria

\section{Abstract}

The aim of this study is to develop a Cost Expectancy Limit Model that could assist clients in having proactive information about construction cost expectation of a particular building type with a view of assisting the client in proactive determination of expected construction cost of a building under predetermined conditions. Two population frames were used in this context. First, a population frame of 1500 samples of actual construction cost of residential building in Lagos state Nigeria out of which 1000 samples of As-built cost (Actual cost) of residential buildings were used, in artificial neural network data training and model development using MATLAB Neuro tools. The second population sample was 250 samples of construction professionals, out of which 200 samples was picked for purpose of questionnaire administration to capture data on factors that could influence building cost expectancy. Mean Item Score, Simple Percentage, and Relative Agreement Index of SPSS package was used to analyze and process the data. Cost expectancy limit was developed with parameters trained with Artificial Neural Networks, while factors that influence the accurateness of the expectancy model were articulated, such as economic factors, political factors, activity of maestros, macro and micro economic variables, and corruption factors, among others. The study recommends the use of the model and strategy for effectiveness in accurate prediction of construction cost among other things. Copyright (C) 2019 ISEC Press.

Author keywords

Agreement; Information; Neuro tools; Parameters; Prediction

Indexed keywords

Topics of prominence (i)

Funding details
Metrics (?) View all metrics >

1 Views Count 2021 (i) Last updated on: 27 April 2021

$9 \quad 2020$

$10 \quad 2011-2021$

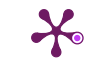

PlumX Metrics

Usage, Captures, Mentions, Social Media and Citations beyond Scopus.

Cited by 0 documents

Inform me when this document is cited in Scopus:

Set citation alert >

Related documents

Building informatics neural network and regression heuristics protocol for making decisions in building construction projects

Amusan, L.M. , Omuh, I.O. , Mosaku, T.O.

(2019) ISEC 2019 - 10th

International Structural

Engineering and Construction

Conference

Exploring factors that influences the adoption of ICT-based building and construction informatic platforms

Lekan, A.M. , Kehinde, A.-Y. , Ignatius, $\mathrm{O}$.

(2019) International Journal of

Civil Engineering and Technology

Conceptual estimation of construction costs using the multistep ahead approach

Dursun, O. , Stoy, C. (2016) Journal of Construction Engineering and Management

View all related documents based on references

Find more related documents in Scopus based on:

Authors > Keywords > 
1 Afolabi, A.O., Oyeyipo, O.O., Ojelabi, R.A., Amusan, L.M.

Construction professionals' perception of a web-based recruiting system for skilled labour

(2018) Journal of Theoretical and Applied Information Technology, 96 (10), pp. 2885-2899. Cited 14 times.

http://www.jatit.org/volumes/Vol96No10/13Vol96No10.pdf

2 Amusan, L.M.

(2012) Neural Network-Based Cost Predictive Model for Building

Works. Cited 3 times.

PhD Thesis, Covenant University, Ota, Nigeria

3 Amusan, L.M., Charles, A.K., Adeyemi, E., Joshua, O., Raphael, O.A.

Data on expert system-econometric entropy informatics model for adjudicating residential building project costs (Open Access)

(2018) Data in Brief, 20, pp. 1721-1729. Cited 5 times. doi: 10.1016/j.dib.2018.08.177

View at Publisher

Amusan, L., Ayo-Yussuf, K., Ogunde, A., Tunji-Olayeni, P., Afolabi, A., Owolabi, J.

Work order building informatics platform for planning residential building projects and maintenance work

(2018) International Journal of Civil Engineering and Technology, 9 (9), pp. 135-146.

http://www.iaeme.com/MasterAdmin/UploadFolder/IJCIET_09_09_016/IJCIET _09_09_016.pdf

5 Boussabaine, A.H.

The use of artificial neural networks in construction management: A review

(1996) Construction Management and Economics, 14 (5), pp. 427-436. Cited 90 times.

http://www.tandf.co.uk/journals/titles/01446193.asp

doi: 10.1080/014461996373296

View at Publisher

6 Buratti, C., Lascaro, E., Palladino, D., Vergoni, M.

Building behavior simulation by means of artificial neural network in summer conditions (Open Access)

(2014) Sustainability (Switzerland), 6 (8), pp. 5339-5353. Cited 17 times. http://www.mdpi.com/2071-1050/6/8/5339/pdf doi: $10.3390 /$ su6085339

View at Publisher 
Sized based software cost modelling with artificial neural network and genetic algorithms

(2011) Artificial Neural Networks - Application

Limassol, Cyprus

Indexed keywords

Topics of prominence

Funding details

8 Elfaki, A.O., Alatawi, S., Abushandi, E.

Using intelligent techniques in construction project cost estimation: 10-Year survey (Open Access)

(2014) Advances in Civil Engineering, 2014, art. no. 107926. Cited 42 times. www.hindawi.com/journals/ace/ doi: 10.1155/2014/107926

View at Publisher

9 Kim, G.-H., An, S.-H., Kang, K.-I.

Comparison of construction cost estimating models based on regression analysis, neural networks, and case-based reasoning

(2004) Building and Environment, 39 (10), pp. 1235-1242. Cited 270 times. doi: 10.1016/j.buildenv.2004.02.013

View at Publisher

10 Jafarzadeh, R., Ingham, J.M., Wilkinson, S., González, V., Aghakouchak, A.A. Application of artificial neural network methodology for predicting seismic retrofit construction costs

(2014) Journal of Construction Engineering and Management, 140 (2), art. no. 04013044 . Cited 19 times.

doi: $10.1061 /($ ASCE)CO.1943-7862.0000725

View at Publisher

11 (2018) MatLab Neuro Tool. $3^{\text {rd }}$ Edition

Mat-lab R2017b, United States of America

12 Offei-Nyako, K., Tham, L.C.O., Bediako, M., Adobor, C.D., Asamoah, R.O. Deviations between contract sums and final accounts: The case of capital projects in ghana

(2016) Journal of Construction Engineering, 2016. Cited 3 times.

1 of 1

$\wedge$ Top of page

\section{About Scopus}

What is Scopus

Content coverage
Language

日本語に切り替える

切换到简体中文
Customer Service

Help

Contact us 
Scopus blog

Abstract Scopus API

切換到繁體中文

AutRoivkeyumoatters

Indexed keywords

Topics of prominence

ELSEVIER

Funding details

Русский язык

Terms and conditions $\pi \quad$ Privacy policy $\pi$

Copyright (C) Elsevier B.V л. All rights reserved. Scopus ${ }^{\circledR}$ is a registered trademark of Elsevier B.V.

We use cookies to help provide and enhance our service and tailor content. By continuing, you agree to the

Q RELX use of cookies. 